Zagazig J. Agric. Res., Vol. 43 No. (3) 2016

http:/www.zu.edu.eg/ journalDisplay.aspx?Journalld=1\&queryType=Master

\title{
DEVELOPMENT OF MACHINE FOR EXTRACTING SISAL FIBER
}

\author{
Ahmed I. Imam ${ }^{\text {* }}$, M.A. Hassan ${ }^{2}$, M.M. Ali ${ }^{2}$ and I.S. Youssef ${ }^{1}$ \\ 1. Agric. Eng. Inst., Agric, Res. Cent., Dokki, Egypt \\ 2. Agric. Eng. Dept., Faculty of Agric. Zagazig Univ., Egypt
}

\begin{abstract}
Filed experiments were carried out to manufacture an extraction machine from locally available materials suitable for extracting sisal fibers and evaluate its performance under field conditions. The extraction machine (decorticator) performance was conducted under four extracting drum speeds of 7.85, 12.57, 17.28 and $22 \mathrm{~m} / \mathrm{sec}$., Three clearances between the knives and the feeding drum of 4 , 7 and $10 \mathrm{~mm}$, three feeding drum speeds of $0.05,0.1$ and $0.15 \mathrm{~m} / \mathrm{sec}$ and three different knife number of 2, 3 and 4. Extraction machine (decorticator) performance was evaluated in terms of machine productivity and efficiency, specific energy and operating cost. The experimental results recommended to use the developed machine under the following condition: extracting drum speed of $22 \mathrm{~m} / \mathrm{sec}$., clearance of $7 \mathrm{~mm}$, feeding speed of $0.15 \mathrm{~m} / \mathrm{s}$ and $3 \mathrm{knives}$.
\end{abstract}

Key words: Sisal extraction machine, decorticator, sisal, drum speeds, knife number, operational costs.

\section{INTRODUCTION}

Sisal fiber is one of the most widely used as a natural fiber and is very easily cultivated. It has short renewal times and grows wild in the hedges of field and railway tracks, 4.5 million tons of sisal fibers are produced every year throughout the world. Tanzania and Brazil are the two main producing countries. Sisal fiber is a hard fiber extracted from the leaves of the sisal plant (Agave sisalana Perrine). Though native to tropical and sub-tropical North and South America, sisal plant is now widely grown in tropical countries of Africa, the West Indies and the Far East (Murherjee and Satyanarayana, 1984), the sisal plant consists of $4 \%$ of fibrous materials only. Sisal fiber is mainly used as ropes in the marine and agricultural industries. Other applications of sisal fibers include twines, cords, upholstery, padding, mat making, fishing nets and fancy articles such as purses, wall hangings, table mats, rugs, sacks for coffee, wagon cover and floor covering. Sentong et al. (2002) described the design and construction of a prototype sisal decorticator for small-scale farmers. The prototype provides for improved

* Corresponding author: Tel. : +201000744563

E-mail address: eng_imam82@yahoo.com sisal processing and can be manufactured locally. Productivity of the prototype was $12 \mathrm{~kg}$ of dry sisal fiber per hour with a design efficiency of $(42.9 \%)$ and yield of (3.2\%). Test results showed that, after decortications, sisal fibers have to be washed, dried and brushed in order to detach some pulp that may have remained on the fibers. Benjamin et al. (2006) constructed and tested an extraction machine decorticator to suit sisal crops fiber consists mainly of steel drum, and four fixed knives. Decorticator was tested at different revolving speeds for drum. He found that increasing the extracting drum speed increased the extraction productivity and machine efficiency. Shipra and Varshney (2012) mentioned that, the juice of the leaves lowers the blood pressure and stimulates their intestinal movements. It possesses ecbolic properties and may be used as an abortifacient as it activates the uterine motility. It is a uterine stimulant, laxative and hypotensive drug .Ashish et al. (2015) showed that, the methods used for extraction of sisal fibers from plant leaves are chemical, retting, mechanical similar to the methods that are used for extraction of flax fibers. There are three major fiber extraction 
methods: mechanical extraction, chemical extraction and retting process. After extraction of fibers by any of these methods, all extracted leaves are washed away before drying. Artificial drying results in higher grade fibers than sun drying. The fibers were dried under a shade to avoid bleaching by direct sunlight. Dry fibers are then combed, sorted into different grades and packed into bales.

So, the objectives of the present work are to:

-Develop and manufacture an extraction machine suitable for extracting sisal fiber.

-Optimize some operating parameters affecting the performance of the developed machine.

-Evaluate the developed machine from the economical point of view.

\section{MATERIALS AND METHODS}

The experiments were carried out at Saft El Hena village, Abu Hammad District; Sharkia Governorate during 2014-2015 season to test and evaluate the performance of the manufactured sisal fiber extraction machine (decorticator) under local conditions.

\section{Materials}

\section{Sisal}

The used sisal crop (Agave sisalana) (Photo. 1) was at an average moisture content of $87.25 \%$, leaf length between $1.0-1.5 \mathrm{~m}$, leaf width between $0.1-0.3 \mathrm{~m}$, leaf thickness varied from $2 \mathrm{~mm}$ to $50 \mathrm{~mm}$, and leaf fiber contain $4 \%$.

\section{Extraction machine}

The extraction machine was constructed from local materials at a local workshop to extract fiber from sisal leaves crop, which consumed more time, effort and cost. The manufactured machine is of $155 \mathrm{~cm}$ length, $123 \mathrm{~cm}$ width and $100 \mathrm{~cm}$ height. The manufactured decorticator is shown in Photo. 2 and Fig. 1.

Table 1 summarizes the specifications of the manufactured sisal fiber extraction machine.

The extraction machine consists of the following main parts:

\section{Knives}

A fixed knife is of rectangular shape made of iron steel with $40 \mathrm{~cm}$ length, $5 \mathrm{~cm}$ width and $5 \mathrm{~cm}$ thickness.

\section{Extracting drum}

The extracting drum made of iron steel with 40 $\mathrm{cm}$ length, and $30 \mathrm{~cm}$ diameter.

\section{Feeding drums}

Two feeding drums were made of iron steel with $40 \mathrm{~cm}$ length, and $10 \mathrm{~cm}$ diameter.

\section{Expulsion drums}

Two expulsion drums were made of iron steel with $40 \mathrm{~cm}$ length, and $10 \mathrm{~cm}$ diameter.

\section{Pulleys}

A set of driving pulleys were developed to accommodate for different extraction and feeding speeds ratios. All pulleys were made of aluminum with different diameters $(30,28,17.5,15,12.5$ and $10 \mathrm{~cm})$ and $2.5 \mathrm{~cm}$ for pulley hole.

\section{Source of power}

Two AC Motors three phases, one of them $3 \mathrm{hp}$ $(2.208 \mathrm{~kW})$, rotating speed of $1450 \mathrm{rpm}$ for extracting fiber process and the second AC Motor $0.75 \mathrm{hp}(0.552 \mathrm{~kW})$ with gear box reduced $(35$ rpm) for feeding process.

\section{Measuring instrument}

The following instrumentations with desirable accuracy were used for different measurements during the execution of experiments: stop watch, electronic balance, caliper, digital tachometer, a wattmeter and clamp meter.

\section{Methods}

The extracting fiber experiments were conducted to optimize some operational parameters affecting the performance of sisal fiber extraction machine. These parameters are:

1.Four extracting drum linear speeds of 7.85 (500), 12.57 (800), $17.28(1100)$ and $22(1400) \mathrm{m} / \mathrm{sec}$ (rpm).

2. Three clearances between the knives and the feeding drum of (4, 7and $10 \mathrm{~mm})$.

3. Three feeding drum linear speeds of 0.05 (10), 0.1 (20) and 0.15 (30) $\mathrm{m} / \mathrm{sec}(\mathrm{rpm})$.

4. Three different knife numbers of (2, 3 and 4). 


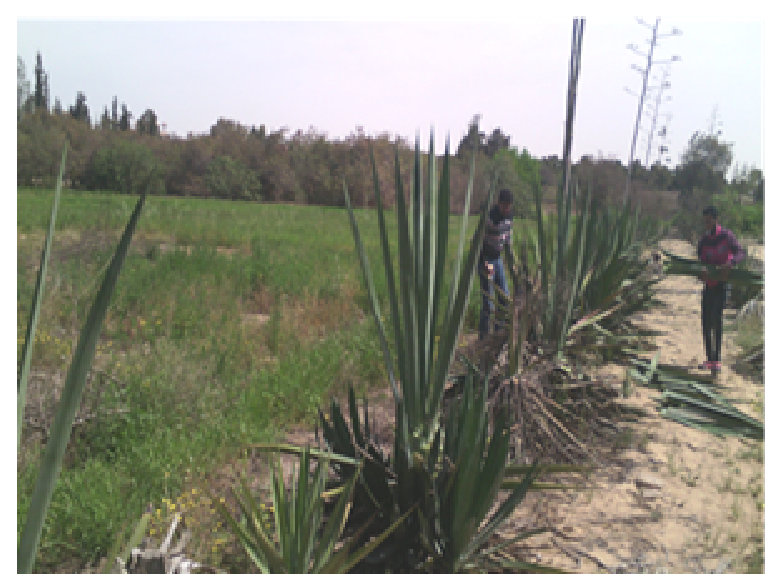

Photo. 1. View of the sisal plant

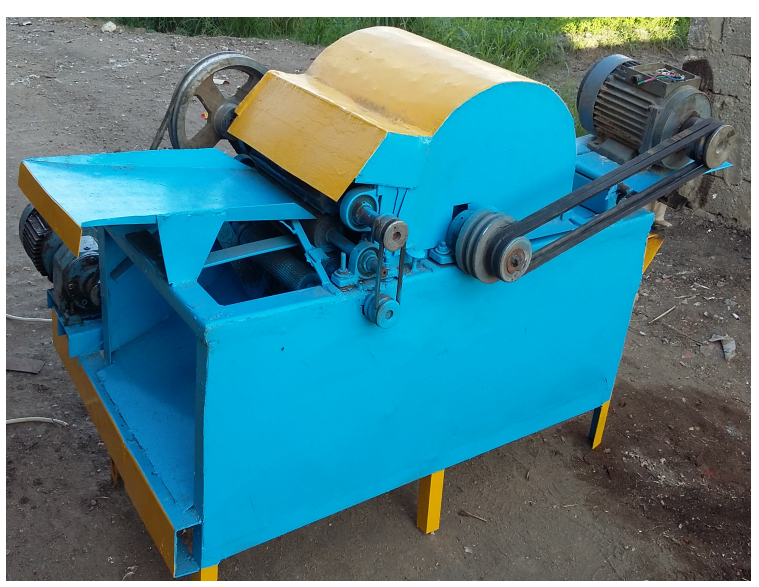

Photo. 2. Extraction machine

Table 1. Specifications of sisal fiber extraction machine

\begin{tabular}{lc}
\hline Item & Specifications of device \\
\hline Model & Local made \\
Overall length & $1.55 \mathrm{~m}$ \\
Overall width & $1.23 \mathrm{~m}$ \\
Overall high & $100 \mathrm{~cm}$ \\
Extracting drum diameter & $30 \mathrm{~cm}$ \\
Extracting drum width & $40 \mathrm{~cm}$ \\
Feeding and Expulsion drums diameter & $10 \mathrm{~cm}$ \\
Feeding and Expulsion drums width & $40 \mathrm{~cm}$ \\
Source of power & Two electrical motors $(2.21,0.55 \mathrm{~kW})$ for extracting process \\
Knife shape & and feeding process \\
Knife number & Rectangular \\
Clearances & From 2 to 4 \\
\end{tabular}




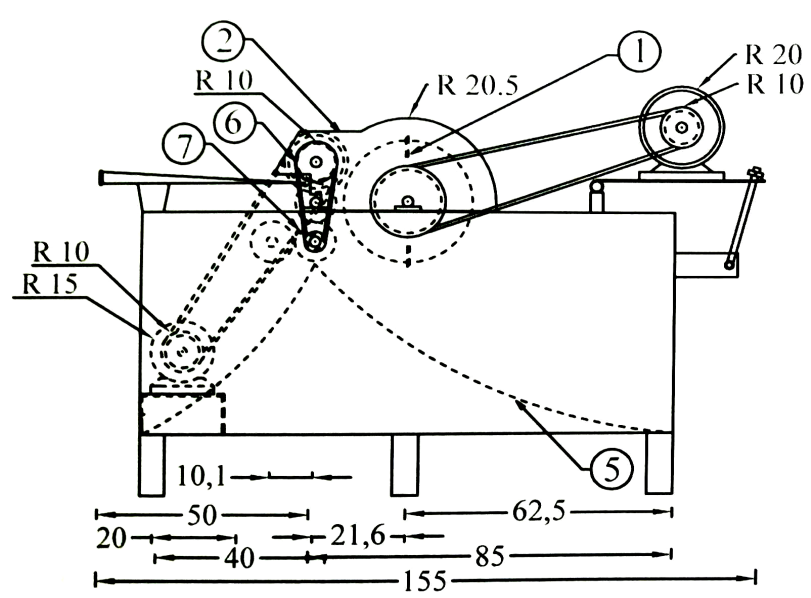

S. view

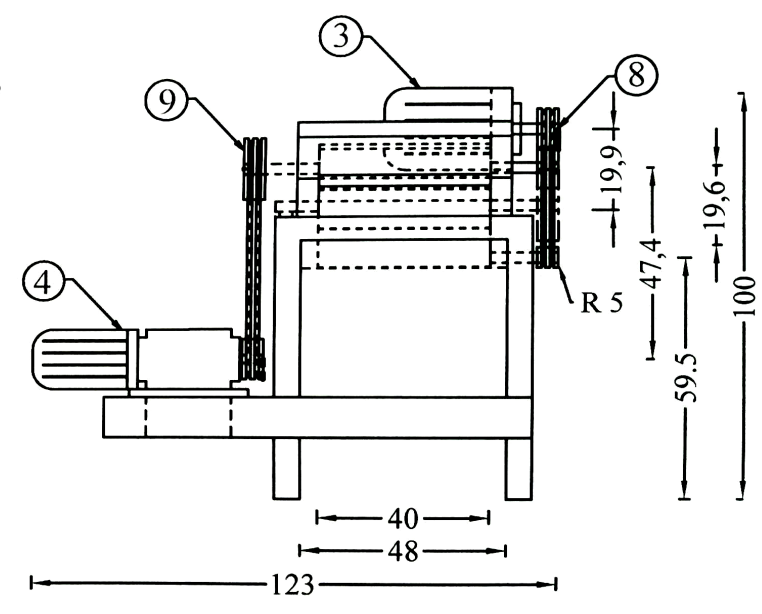

Elevation

\begin{tabular}{|c|c|c|c|c|c|c|c|}
\hline No. Part name & No. of part & No. & Part name & No. of part & No. & Part name & No. of part \\
\hline 1 Extraction drum & 1 & 4 & AC motor+ gear box & 1 & 7 & Expulsion drums & 2 \\
\hline 2 Cover & 1 & 5 & Concave & 1 & 8 & Pulleys of extracting drum & 4 \\
\hline 3 AC motor & 1 & 6 & Feeding drums & 2 & 9 & Pulleys of feeding drum & 3 \\
\hline
\end{tabular}

Fig. 1. Schematic view of the sisal fiber extraction machine

\section{Procedures}

A given quantity of $5 \mathrm{~kg}$ mass of sisal leaves was extracted in the decorticator machine after adapting extracting drum speed, clearances, feeding drum speeds and the knife number. The elapsed time to complete the sample processing is measured and recorded and total consumed $(\mathrm{kW})$ under working load was determined by using a wattmeter (700-k type). The processed sample was received in a special container to measure its fiber mass and pulp it to different parameters. The process is repeated 3 times for each combination of different study parameters.

\section{Measurements}

Evaluation of the sisal fiber extraction machine performance was carried out taking into consideration the following indicators:

\section{Machine productivity and efficiency}

\section{Productivity of the sisal fiber extraction} machine

It is the rate of machine productivity in the time unit $(\mathrm{Mg} / \mathrm{hr})$.

Efficiency of the sisal fiber extraction machine

Machine efficiency $=\frac{\text { Wout }}{\text { Win }} \times 100$
Where:

Wout $=$ output (yield mass, $\mathrm{Mg}$ ).

Win = input (sample mass, $\mathrm{Mg}$ ).

Sisal fiber productivity and extracting fiber efficiency

\section{Sisal fiber productivity}

It is the rate of fiber productivity in the time unit $(\mathrm{Mg} / \mathrm{hr})$.

\section{Extracting fiber efficiency}

Extracting fiber efficiency $=\frac{\text { Wf out }}{\text { Wf in }} \times 100$

Where:

Wf out $=$ mass of dried extracted fiber output (fiber mass, $\mathrm{Mg}$ )

Wf in = mass of potential fiber content (fiber sample mass, $\mathrm{Mg}$ )

Wf in $=$ Win $\mathrm{x}(4 \%), 4 \%=$ fiber percentage in a leaves (Murherjee and Satyanarayana, 1984).

\section{Extracting power and specific energy}

The required extracting power was estimated by using the following equation (Kurt, 1979)

Total consumed power $=\frac{\sqrt{3} \mathrm{I} \cdot \mathrm{V} \eta \cdot \mathrm{V} \eta \mathrm{c}}{1000}$ $(\mathrm{kW})$ 
Where:

$\mathrm{I}=$ line current strength in Amperes, $\mathrm{V}=$ Potential strength (voltage) equal to $380 \mathrm{~V}$, $\cos \Theta=$ power factor (equal to 0.84 ) and $\eta=$ Mechanical efficiency.

The specific energy (kW.hr./Mg) was calculated by using the following equation:

Specific energy $=$ the consumed power $(\mathrm{kW}) /$ extraction machine productivity $(\mathrm{Mg} / \mathrm{hr})$.

\section{Machine unit operating cost}

Machine unit operating cost (LE/Mg)

$$
=\frac{\text { Machine cost ( } \mathrm{LE} / \mathrm{hr} \text {.) }}{\text { Machine productivity }(\mathrm{Mg} / \mathrm{hr} \text {.) }}
$$

The machine cost was determined by using the following formula (Awady, 1978):

$\mathrm{C}=(\mathrm{p} / \mathrm{h})(1 / \mathrm{a}+\mathrm{i} / 2+\mathrm{t}+\mathrm{r})+(\mathrm{W} * \mathrm{e})+\mathrm{m} / 288$

Where:

C: Machine hourly cost, LE./h; P: Price of machine, 7000 LE; h: Yearly working hours, $3500 \mathrm{hr}$; a: Life expectancy of the machine, 10 year; i: Interest rate, $10 \%$; t: Taxes and over heads ratio, 10\%; r: Repairs and maintenance ratio, $10 \%$; W: Power of motor in, $\mathrm{kW}$; e: electricity cost, 0.34 LE /kW.hr.; m: The monthly average wage, $1500 \mathrm{LE}$; and 288: The monthly average working hours $(12 \mathrm{hr} . \times 6$ days $\times 4$ weeks).

\section{RESULTS AND DISCUSSION}

\section{Machine Productivity and Efficiency}

Effect of extracting drum speed on machine productivity and efficiency

Results in Figs. 2 and 3 show relationship between extracting drum speed and machine productivity. It's noticed that increasing extracting drum speed from 7.85 to $22 \mathrm{~m} / \mathrm{sec}$., caused increase in productivity from 0.072 to 0.144 and from 0.108 to 0.180 and from 0.128 to $0.235 \mathrm{Mg} / \mathrm{hr}$., for feeding speeds of $0.05,0.10$ and $0.15 \mathrm{~m} / \mathrm{sec}$., respectively under constant clearance between the knives and the feeding drum of $10 \mathrm{~mm}$ and knife numbers of 3 . On the other hand, increasing extracting drum speed from 7.85 to $22 \mathrm{~m} / \mathrm{s}$ lead to increase the machine efficiency from 71.81 to 86.32 , from 78.21 to 90.02 , and from 74.22 to $88.05 \%$, under the same previous conditions. Increasing extracting drum speed causes more extracting action at the leaves, which led to more separating of the fiber and more machine efficiency. While increasing the extracting drum speed more than 17.28 $\mathrm{m} / \mathrm{sec}$ decreased the machine efficiency. Hence, the machine efficiency takes the opposite trend of the machine capacity with high extracting drum speeds.

\section{Effect of clearance on machine productivity and efficiency}

Figs. 2 and 3 display the relation between clearances between the knives and the feeding drum and machine productivity and efficiency. Hence, it appears that, increasing the clearance between the knives and the feeding drum from 4 to $10 \mathrm{~mm}$, the values of productivity increased from 0.113 to 0.144 , from 0.147 to 0.180 and from 0.180 to $0.235 \mathrm{Mg} / \mathrm{hr}$., for feeding speeds of $0.05,0,10$ and $0.15 \mathrm{~m} / \mathrm{s}$, respectively under extracting drum speed of $22 \mathrm{~m} / \mathrm{sec}$ and knife number of 3. On the other hand, changing clearances between the knives and the feeding drum from, 4 to $10 \mathrm{~mm}$, the values of machine efficiency changed from 85.25 to 89.92 , from 88.12 to 93.21 and from 85.12 to $90.34 \%$ for feeding speed of $0.05,0.10$ and $0.15 \mathrm{~m} / \mathrm{sec}$, respectively, under extracting drum speed of $17.28 \mathrm{~m} / \mathrm{sec}$. and knife number of 3 . The increase in machine efficiency by increasing the clearance between the knives and the feeding drum from 4 to $10 \mathrm{~mm}$ may be due to ease passage product from inside the machine that means decreasing in the treatment consumed time and reduce the losses.

\section{Effect of feeding speed on machine productivity and efficiency}

Results in Figs. 2 and 3 show that, increasing feeding speed from 0.05 to $0.15 \mathrm{~m} / \mathrm{sec}$ leads to increase the machine productivity from 0.072 to 0.128 , from 0.111 to 0.179 , from 0.128 to 0.207 and from 0.144 to $0.235 \mathrm{Mg} / \mathrm{hr}$ at extracting drum speeds of 7.85,12.57,17.28 and $22 \mathrm{~m} / \mathrm{sec}$, respectively. Under clearance between the knives and the feeding drum of $7 \mathrm{~mm}$ and knife number of 3 . Also, increasing feeding speed 

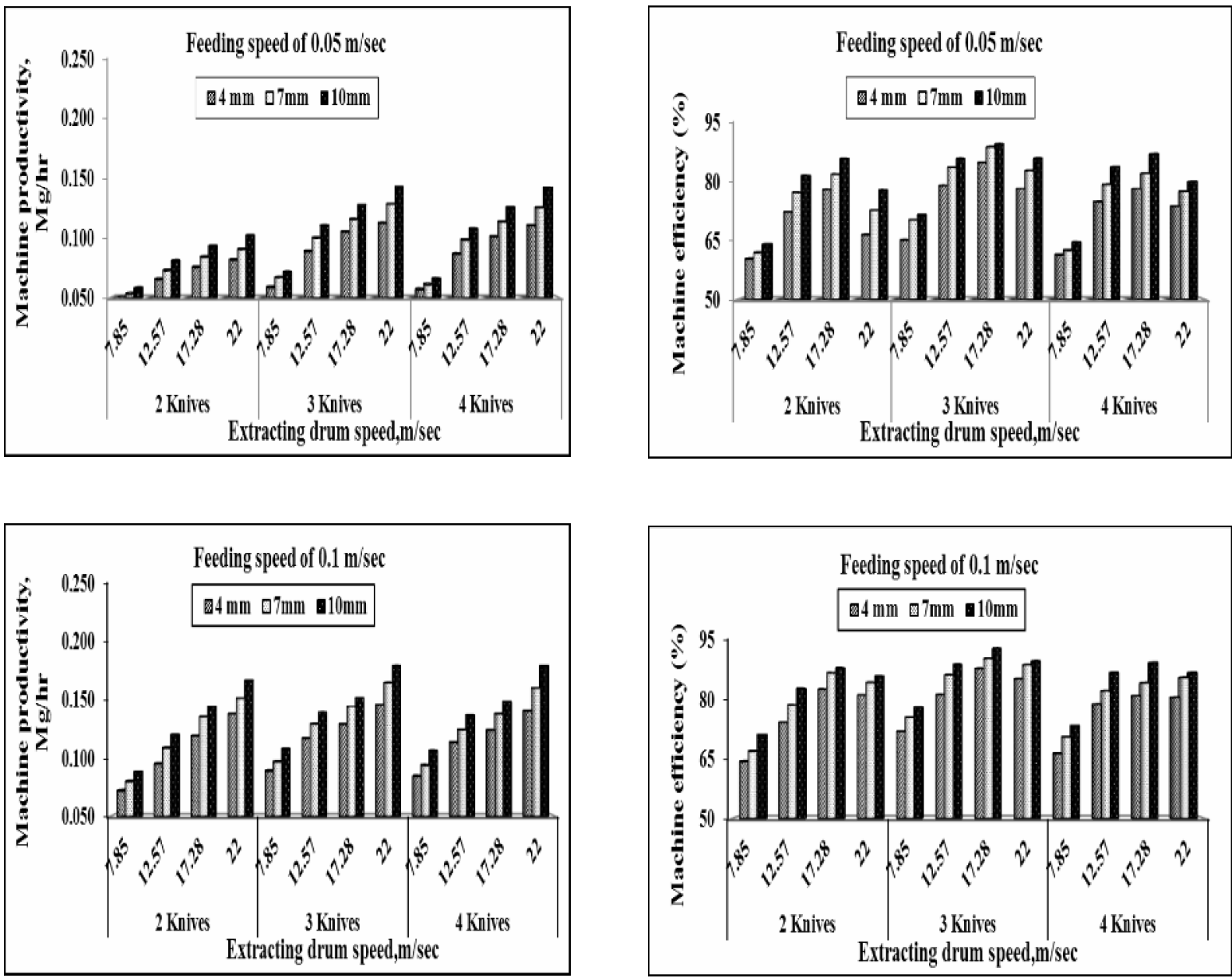

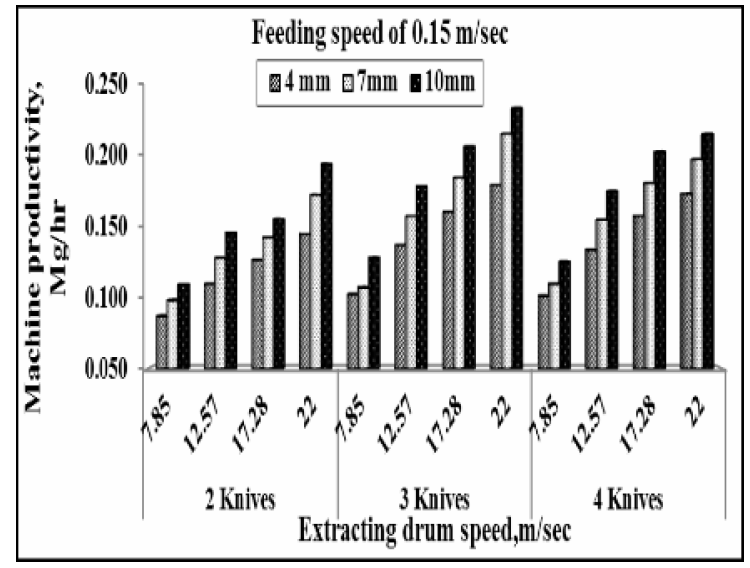

Fig. 2. Effect of extracting drum speed on machine productivity under different clearances, and knife number using feeding speeds of $0.05,0.1$ and 0.15 $\mathbf{m} / \mathbf{s e c}$.

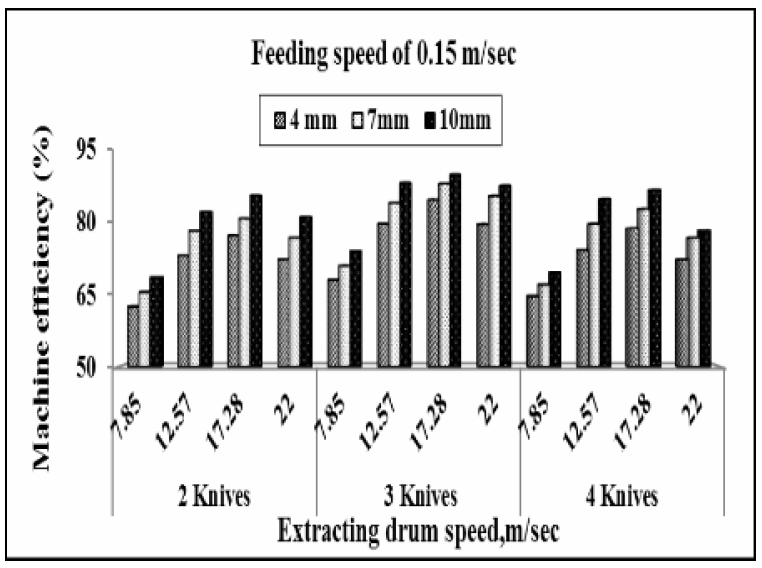

Fig. 3. Effect of extracting drum speed on machine efficiency under different clearances, and knife number using feeding speeds of $0.05,0.1$ and 0.15 $\mathbf{m} / \mathbf{s e c}$. 
leads to increase machine efficiency from 71.81 to 74.22 , from 86.23 to 88.63 , from 89.92 to 90.34 , and from 86.32 to $88.05 \%$, under the same previous conditions, at clearances between the knives and the feeding drum of $10 \mathrm{~mm}$ and knife number of 3 .

\section{Effect of knife number on machine productivity and efficiency}

Results in Figs. 2 and 3 show that increasing number of knives from 2 to 4 , the production rate increased from 0.103 to 0.143 , from 0.168 to 0.180 and from 0.195 to $0.216 \mathrm{Mg} / \mathrm{hr}$ for feeding speed of $0.05,0,10$ and 0.15 , respectively, using extracting drum speed of 22 $\mathrm{m} / \mathrm{s}$ and clearance between the knives and the feeding drum of $10 \mathrm{~mm}$ Also, increasing number of knives from 2 to 4 lead to increase the machine efficiency from 86.21 to 89.92 , from 88.29 to 93.21 and from 85.98 to $90.34 \%$ for feeding speeds of $0.05,0.10$ and $0.15 \mathrm{~m} / \mathrm{sec}$, respectively, using extracting drum speed of $17.28 \mathrm{~m} / \mathrm{sec}$ and clearance between the knives and the feeding drum of $10 \mathrm{~mm}$. Increasing the knife number to 4 decreased the machine efficiency under all clearances, extracting drum speeds, and feeding speed. The increase in machine efficiency by increasing the number of knives from 2 to 3 could be due to increase the number of cutting edges which facilitated the extraction process. Meanwhile, the machine efficiency decreased by increasing the knife numbers to 4 . This phenomenon is attributed to the cutting and pressing leaves caused by the reduced spacing between knives and the increase of knives knocking number in time unit on the leaves due to increasing the cutting fiber and moisture losses.

\section{Sisal Fiber Productivity and Extracting Fiber Efficiency}

\section{Effect of extracting drum speed on sisal fiber productivity and extracting fiber efficiency}

Results in Figs. 4 and 5 show a remarkable drop in the extracting fiber efficiency with a consequent sharp rise in fiber productivity as the extracting drum speed increased. Results show that, increasing extracting drum speed from 7.85 to $22 \mathrm{~m} / \mathrm{sec}$ caused increase in fiber productivity from 0.0031 to 0.051 , from 0.0045 to 0.0063 and from 0.0049 to $0.0081 \mathrm{Mg} / \mathrm{hr}$., for feeding speeds of $0.05, \quad 0.10$ and $0.15 \mathrm{~m} / \mathrm{sec}$, respectively under clearance between the knives and the feeding drum of $7 \mathrm{~mm}$ and knife number of 3 .On the other hand, increasing extracting drum speed from 7.85 to $22 \mathrm{~m} / \mathrm{sec}$ lead to increase the extracting fiber efficiency from 79.63 to 79.03 , from 81.65 to 82.49 and from 76.87 to $87.18 \%$, under the same previous conditions. Increasing extracting drum speed from 7.85 to $17.28 \mathrm{~m} / \mathrm{sec}$. causes more extracting action at the leaves, which leads to more separating of the fiber and increased machine efficiency for extracting fiber. While increasing the extracting drum speed more than $17.28 \mathrm{~m} / \mathrm{sec}$. caused the machine efficiency for extracting fiber to decline. Hence, decreased extracting fiber efficiency takes the opposite trend of the productivity machine of fiber with high extracting drum speeds.

\section{Effect of clearance on sisal fiber productivity and extracting fiber efficiency}

Figs. 4 and 5 display the relation between clearances between the knives and the feeding drum and sisal fiber productivity and extracting fiber efficiency. Hence, it appears that, the fiber productivity increased by changing the clearance between the knives and the feeding drum from, 4 to $10 \mathrm{~mm}$, the values of fiber productivity increased from 0.0044 to 0.0051 , from 0.0055 to 0.0063 and 0.0068 to $0.0081 \mathrm{Mg} / \mathrm{hr}$., for feeding speeds of $0.05, \quad 0.10$ and $0.15 \mathrm{~m} / \mathrm{sec}$., respectively under extracting drum speed of 22 $\mathrm{m} / \mathrm{sec}$., and knife number of 3 . The values of extracting fiber efficiency changed by increasing clearance between the knives and the feeding drum from 4 to10 $\mathrm{mm}$ they increased from 83.93 to 85.71 , from 89.29 to 92.86 and from 85.71 to $88.57 \%$ for feeding speeds of $0.05,0.10$ and $0.15 \mathrm{~m} / \mathrm{sec}$., respectively, under extracting drum speed of $17.28 \mathrm{~m} / \mathrm{sec}$. and knife numbers of 3 . The increase in extracting fiber efficiency by increasing the clearance between the knives and the feeding drum from 4 to $7 \mathrm{~mm}$ may be due to ease passage product from inside the machine that means decreasing in the treatment consumed time and reduce the losses. While increasing the clearance from more than $7 \mathrm{~mm}$ decreased the extracting fiber efficiency. This could be attributed to the increase sisal pulp that stuck with fiber which leads to increasing losses. 

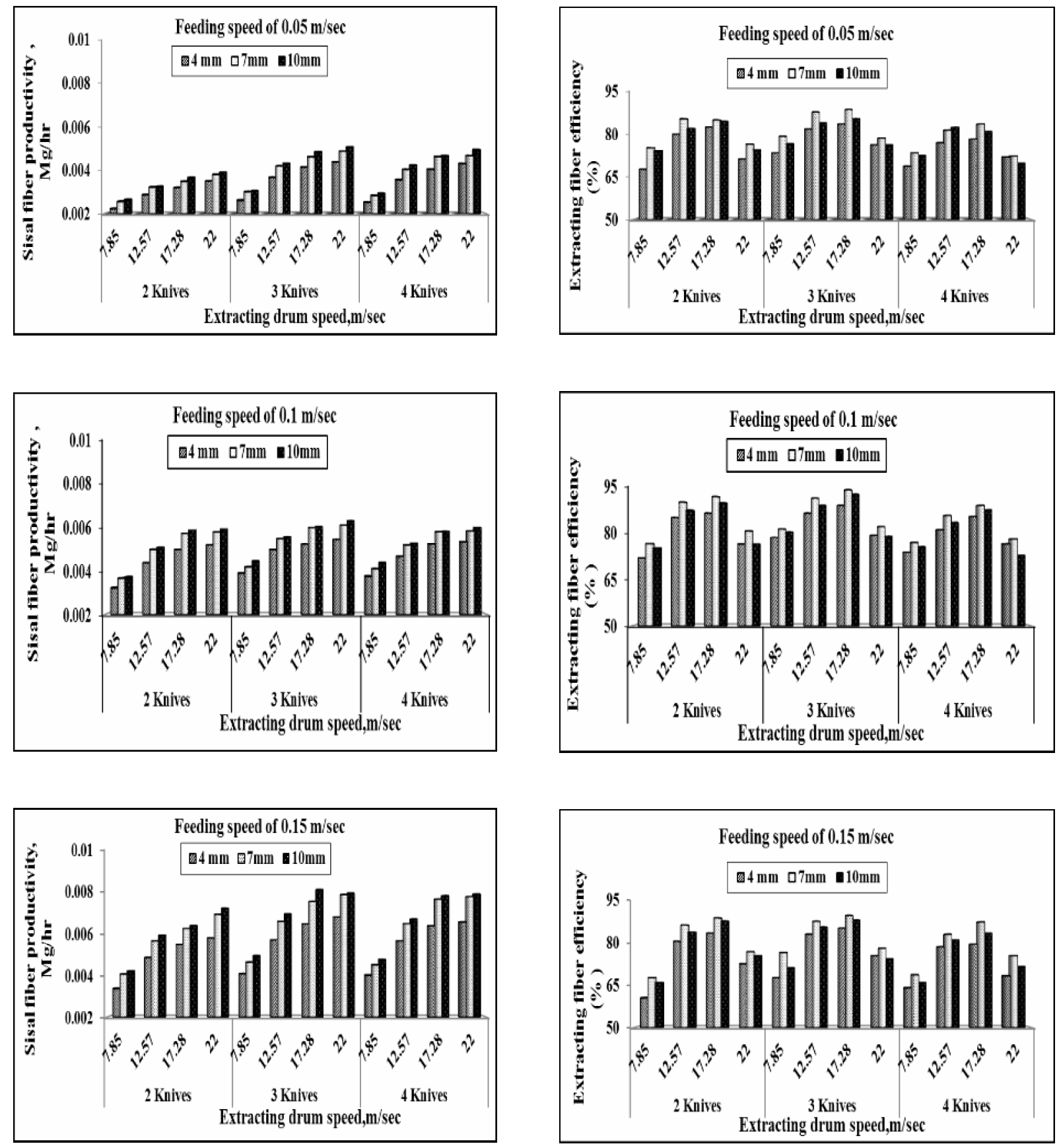

Fig. 4. Effect of extracting drum speed on sisal fiber productivity under different clearances, and knife number using feeding speeds of $0.05,0.1$ and 0.15 $\mathbf{m} / \mathbf{s e c}$.

Fig. 5. Effect of extracting drum speed on extracting fiber efficiency under different clearances, and knife number using feeding speeds of $0.05,0.1$ and $0.15 \mathrm{~m} / \mathrm{sec}$. 
Effect of feeding speed on sisal fiber productivity and extracting fiber efficiency

Results in Figs. 4 and 5 show that, increasing feeding speed from 0.05 to $0.15 \mathrm{~m} / \mathrm{sec}$., leads to increase the fiber productivity from 0.0031 to $0.0049 \mathrm{Mg} / \mathrm{hr}$, from 0.0043 to 0.007 , from 0.0049 to 0.0081 and from 0.0051 to 0.0081 $\mathrm{Mg} / \mathrm{hr}$ at extracting drum speeds of $7.85,12.57$, 17.28 and $22 \mathrm{~m} / \mathrm{sec}$., respectively. Also, increasing feeding speed leads to increase the extracting fiber efficiency from 79.63 to 76.87 , from 88.12 to 88.1 , from 89 to 90.18 , and from 79.03 to $78.38 \%$ under the same previous conditions, at clearance between the knives and the feeding drum and the number of knives of 7 $\mathrm{mm}$ and $3 \mathrm{knives}$, respectively.

Effect of knife number on sisal fiber productivity and extracting fiber efficiency

Figs. 4 and 5 illustrate the fiber productivity as it affected by knives number. Results show that, increasing number of knives from 2 to 4 leads to increase fiber productivity from 0.0039 to 0.005 , from 0.006 to 0.006 and from 0.0072 to $0.0079 \mathrm{Mg} / \mathrm{hr}$ for feeding speeds of $0.05,0.10$ and $0.15 \mathrm{~m} / \mathrm{s}$, respectively, using extracting drum speed of $22 \mathrm{~m} / \mathrm{sec}$ and clearance between the knives and the feeding drum of $10 \mathrm{~mm}$. Also, increasing number of knives from 2 to 4 leads to increase the extracting fiber efficiency from 85.36 to 89 , from 92.14 to 94.31 and from 89.29 to $90.18 \%$ for feeding speeds of 0.05 , 0.10 and $0.15 \mathrm{~m} / \mathrm{sec}$, respectively, using extracting drum speed of $17.28 \mathrm{~m} / \mathrm{sec}$ and clearance between the knives and the feeding drum of $7 \mathrm{~mm}$. Increasing the knife number to 4 decreased the extracting fiber efficiency due to increase the number of cutting edges which facilitated the extracting process.

\section{Specific Energy}

\section{Effect of extracting drum speed on specific energy}

Results in Fig. 6 show that, increasing extracting drum speed leads to decrease specific energy to process the unit mass of sisal leaves. The specific energy of 59.98, 44.53, 41.87 and $40.52 \mathrm{~kW} . \mathrm{hr} / \mathrm{Mg}$, and specific energy of 41.71 , $36.89,36.5$ and $33.55 \mathrm{~kW} . \mathrm{hr} / \mathrm{Mg}$ were measured at feeding speeds of 0.05 and $0.1 \mathrm{~m} / \mathrm{sec}$., respectively using knife number of 3 and clearance between the knives and the feeding drum of $10 \mathrm{~mm}$, also the specific energy of $36.39,29.59,27.64$ and $26.4 \mathrm{~kW} . \mathrm{hr} / \mathrm{Mg}$ was found under the same condition but at feeding speed of $0.15 \mathrm{~m} / \mathrm{s}$, under extracting drum speeds of $7.85,12.57,17.28$ and $22 \mathrm{~m} / \mathrm{sec}$ respectively. Therefore, it appears that lower specific energy was obtained at the higher extracting drum speed. This attributed to increasing machine productivity at higher speeds.

\section{Effect of clearance on specific energy:}

Results in Fig. 6 show that, increasing clearance between the knives and the feeding drum leads to decrease specific energy. The specific energy at clearances of 4, 7 and $10 \mathrm{~mm}$ was found to be 51.56, 45.19 and 40.52 $\mathrm{kW} . \mathrm{hr} . \mathrm{Mg}$ at extracting drum speed of 22 $\mathrm{m} / \mathrm{sec}$, feeding speed of $0.05 \mathrm{~m} / \mathrm{sec}$ and knife numbers of 3. Also, the specific energy of 41.20 , 36.47 and $33.55 \mathrm{~kW} . \mathrm{hr} / \mathrm{Mg}$ was recorded at the same conditions but at feeding speed of $0.1 \mathrm{~m} / \mathrm{s}$. On the other hand, the specific energy of 34.42 , 28.69 and $26.4 \mathrm{~kW} . \mathrm{hr}$./Mg were recorded at the same conditions but feeding speed of $0.15 \mathrm{~m} / \mathrm{sec}$, all under clearance between the knives and the feeding drum of 4, 7 and $10 \mathrm{~mm}$,respectively. Therefore, it appears that lower specific energy was obtained at widest clearance between the knives and the feeding drum of $10 \mathrm{~mm}$. This attributed to increasing of machine productivity is higher than increasing in power required rate.

\section{Effect of feeding speed on specific energy}

The obtained data in Fig. 6 indicate that, increasing the feeding speed of sisal leaves from 0.05 to $0.15 \mathrm{~m} / \mathrm{sec}$ decreased the specific energy from 59.98 to 36.29 , from 44.53 to 29.59 , from 41.87 to $27.64 \mathrm{~kW} . \mathrm{hr} . \mathrm{Mg}$ and from 40.52 to 26.4 at extracting drum speed of 7.85 and 22 $\mathrm{m} / \mathrm{sec}$., respectively under clearance between knives and feeding drum of $10 \mathrm{~mm}$ and knife number of 3. Therefore, it appears that, lower specific energy was obtained at the higher feeding speed. This attributed to increasing of machine productivity at higher feeding speeds.

\section{Effect of knife number on specific energy}

Results in Fig. 6 show that, increasing knife number from 2 to 3 leads to decrease specific energy while increasing it to 4 tends to increase the specific energy. The specific energy of 
$56.82,40.52$ and $40.83 \mathrm{~kW} . \mathrm{hr} / \mathrm{Mg}$ were recorded at extracting drum speed of $22 \mathrm{~m} / \mathrm{sec}$, clearance between the knives and the feeding drum of 10 $\mathrm{mm}$ and feeding speeds $0.05 \mathrm{~m} / \mathrm{sec}$, also the specific energy of $36.05,33.55$ and 33.56 $\mathrm{kW} \cdot \mathrm{hr} / \mathrm{Mg}$ were recorded at the same conditions but at feeding speed of $0.1 \mathrm{~m} / \mathrm{sec}$. On the other hand, the specific energy of 31.76, 26.4 and $28.69 \mathrm{~kW} . \mathrm{hr} / \mathrm{Mg}$ were recorded at the same conditions but at feeding speed of $0.15 \mathrm{~m} / \mathrm{sec}$., all under knives numbers of 2,3 and 4 respectively. Therefore, it appears that, lower specific energy was obtained at knife number of 3 knives. This attributed to increasing of machine productivity.

\section{Operational Cost}

\section{Effect of extracting drum speed on operational cost}

Results in Fig. 7 show that, increasing extracting drum speed leads to decrease operational cost. The operational costs were $99.88,66.63,58.85$ and $53.46 \mathrm{LE} / \mathrm{Mg}$ using clearance between the knives and the feeding drum of $10 \mathrm{~mm}$, feeding speed of $0.05 \mathrm{~m} / \mathrm{sec}$, and knife number of 3 , also the operational costs were $66.90,53.45,49.84$ and $43.11 \mathrm{LE} / \mathrm{Mg}$ at the same conditions but at feeding speed of 0.1 $\mathrm{m} / \mathrm{sec}$, while the operational costs were 56.81 , 41.91, 36.95 and 33.29 LE / Mg at feeding speed of $0.15 \mathrm{~m} / \mathrm{sec}$, using clearance between the knives and the feeding drum of $10 \mathrm{~mm}$ and number of knives 3 , for extracting drum speed of $7.85,12.57,17.28$ to $22 \mathrm{~m} / \mathrm{sec}$., respectively. Same trend of this relationship was found at other operational parameters. Therefore, it appears that lower operational cost was obtained at the higher extracting drum speeds. This attributed to increasing in productivity.

\section{Effect of clearance on operational cost}

Results in Fig. 7 show that increasing clearance between the knives and the feeding drum leads to decrease operational cost. The operational costs of $68.02,59.62$ and $53.46 \mathrm{LE}$ $/ \mathrm{Mg}$, were calculated at feeding speed of 0.05 $\mathrm{m} / \mathrm{sec}$, using extracting drum speed of $22 \mathrm{~m} / \mathrm{sec}$, and knife number of 3 knives, also the operational costs of 52.94, 46.87 and $43.11 \mathrm{LE}$ $/ \mathrm{Mg}$ were found at feeding speed of $0.1 \mathrm{~m} / \mathrm{sec}$., using extracting drum speed of $22 \mathrm{~m} / \mathrm{sec}$. and knife numbers of 3 knives. On the other hand, the operational cost of $43.41,36.18$ and 33.29 $\mathrm{LE} / \mathrm{Mg}$ were noticed at feeding speed of 0.15 $\mathrm{m} / \mathrm{sec}$., using extracting drum speed of $22 \mathrm{~m} / \mathrm{sec}$. and knife numbers of 3 knives, where clearance between the knives ,the feeding drum were 4, 7 and 10, respectively. Therefore, it appears that lower operational cost was obtained at the widest clearance of $10 \mathrm{~mm}$. This attributed to increasing in machine productivity.

\section{Effect of feeding speed on operational cost}

Results in Fig. 7 show that, using feeding speed of $0.15 \mathrm{~m} / \mathrm{sec}$, leads to decrease operational costs compared to all feeding speeds. Increasing feeding speed from 0.05 to $0.15 \mathrm{~m} / \mathrm{sec}$, decreased the operational costs from 99.88 to 56.81 , from 66.63 to 41.91 , from 58.85 to 36.95 and from 53.46 to $33.29 \mathrm{LE} / \mathrm{Mg}$ at extracting drum speeds of $7.85,12.57,17.28$ and $22 \mathrm{~m} / \mathrm{sec}$, respectively under clearance between the knives and the feeding drum of 10 $\mathrm{mm}$ and knife number of 3 . The same trends of this relationship were found at other different combination of clearance between the knives and the feeding drum, and number of knives. Therefore, it appears that lower operational cost was obtained at feeding speed of $0.15 \mathrm{~m} / \mathrm{sec}$. This attributed to increasing in machine productivity.

\section{Effect of knife number on operational cost}

Results in Fig. 7 show that, increasing knife number from 2 to 3 leads to decrease operational cost, while increasing it to 4 caused a slight increase of operational cost. The incurred operational costs of 74.96, 53.46 and $53.86 \mathrm{LE} /$ $\mathrm{Mg}$ were found at feeding speed of $0.05 \mathrm{~m} / \mathrm{sec}$., using extracting drum speed of $22 \mathrm{~m} / \mathrm{sec}$., and clearance between the knives and the feeding drum of $10 \mathrm{~mm}$, also operational costs of 46.32 , 43.11 and $43.12 \mathrm{LE} / \mathrm{Mg}$ were found at feeding speed of $0.1 \mathrm{~m} / \mathrm{sec}$., using extracting drum speed of $22 \mathrm{~m} / \mathrm{sec}$., and clearance between the knives and the feeding drum of $10 \mathrm{~mm}$, while operational cost of 40.09, 33.29 and 36.18 LE / $\mathrm{Mg}$ at feeding speed of $0.15 \mathrm{~m} / \mathrm{sec}$, using extracting drum speed of $22 \mathrm{~m} / \mathrm{sec}$. and clearance between the knives and the feeding drum of $10 \mathrm{~mm}$, where knives numbers were 2 , 3 and 4, respectively. Therefore, it appears that lower operational cost was obtained at the knife number of 3 knives. This attributed to increasing in machine productivity. 

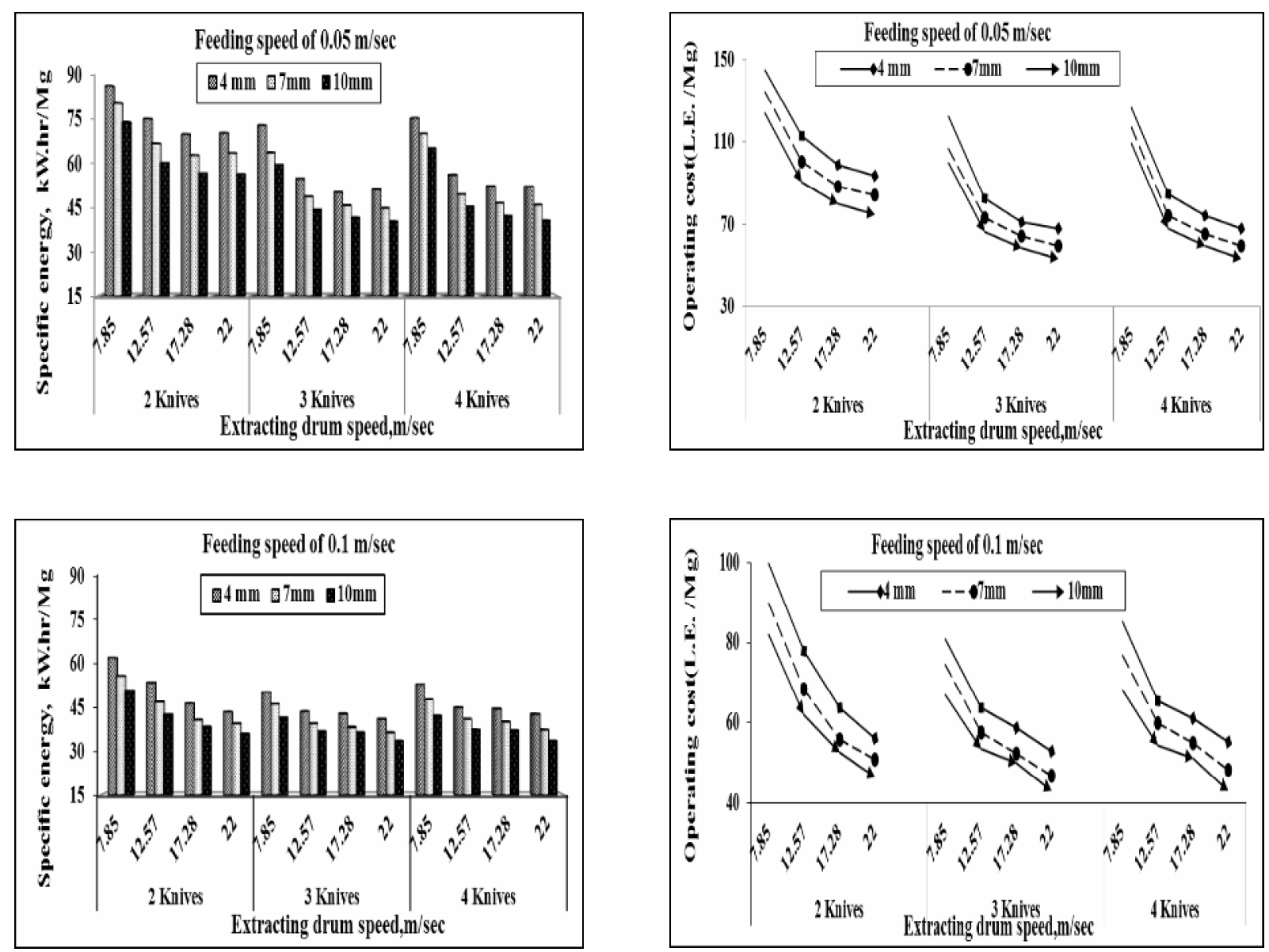

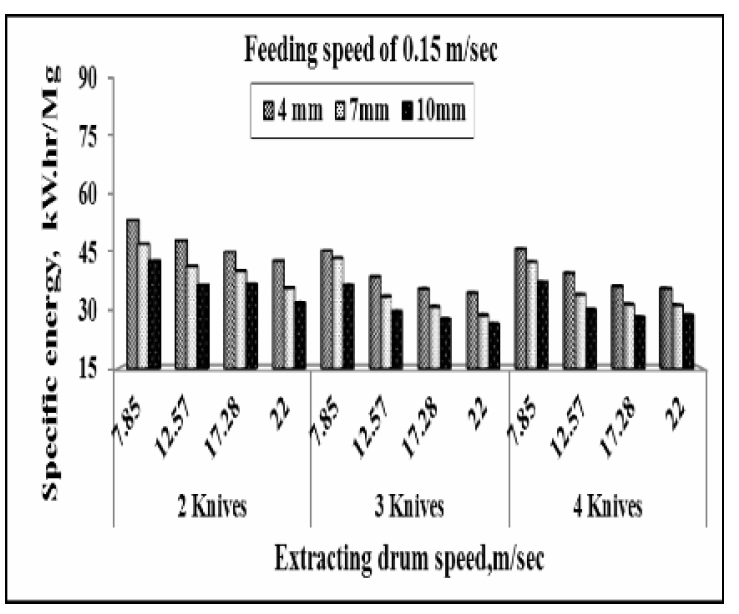

Fig. 6. Effect of extracting drum speed on specific energy under different clearances, and knife number using feeding speeds of $0.05,0.1$ and 0.15 $\mathrm{m} / \mathbf{s e c}$.

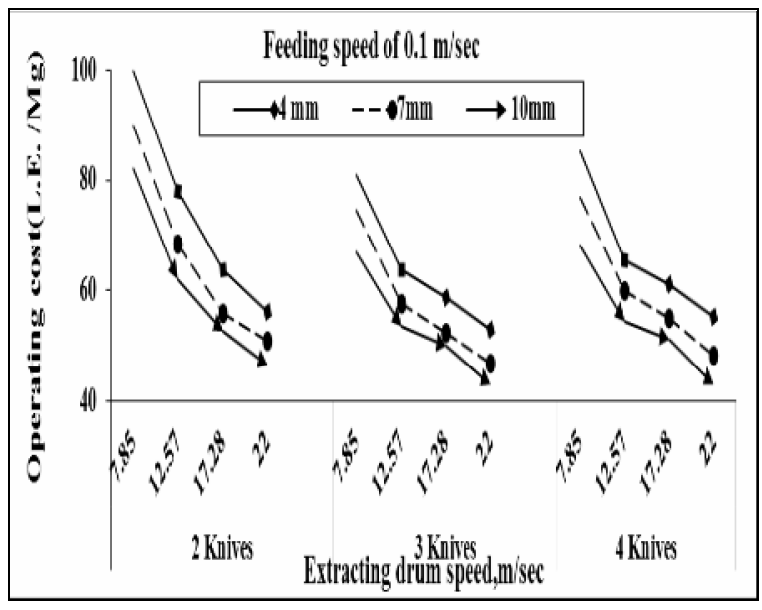

Fig. 7. Effect of extracting drum speed on operational cost under different clearances, and knife number using feeding speeds of $0.05,0.1$ and 0.15 $\mathbf{m} / \mathbf{s e c}$. 


\section{REFERENCES}

Ashish, H., K. Pradyumkumar and K. Pooja (2015). Agave Americana leaf fibers. fiber open access J., 1(3): 64-75.

Awady, M.N., I. Yehia, M.T. Ebaid and E.M. Arif (1978). Development and theory of rice cleaner for reducing impurities and losses. Misr J.of Agric. Eng., Oct., v. (n): 53-68.

Benjamin, J., S. Joe, B.J. Dolak and T. Weiser (2006). A portable sisal decorticator for Kenyan farmers. Int. J. for Service Learning in Eng., 2 (1): 92-116.

Kurt, G. (1979). Engineering Formulas. $3^{\text {rd }}$ Ed. Mc Graw- Hill book Co.
Murherjee, P.S. and K.G. Satyanarayana (1984). Structure and properties of some vegetable fibers, part 1. Sisal fiber. J. Materials Sci., 19: 3925-3934.

Sentong, J., J.B. Kawongolo and L. Bro and J.B. Kawongolo (2002). Design of a decorticator for small scale sisal processing in Uganda. Am. Soc. Agric. Engin. J., 10 (026202) : 590598.

Shipra, S. and V. K. Varshney (2012). Chemical analysis of agave sisalana juice for its possible utilization. Acta Chim. Pharm. Indica: 2(1): 60-66.

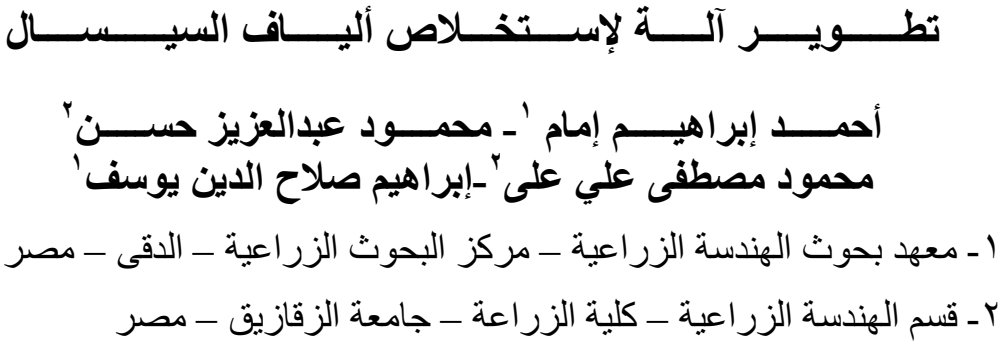

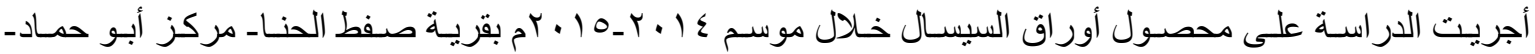

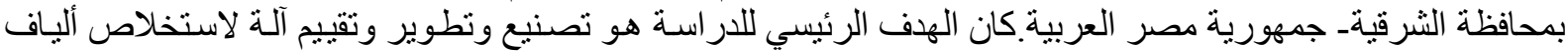

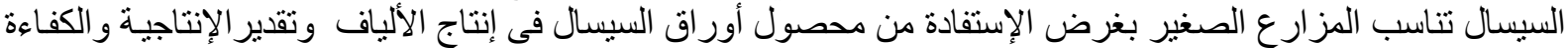

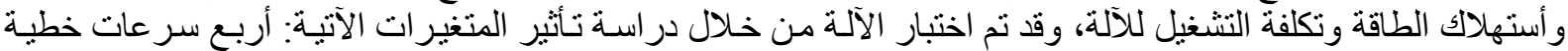

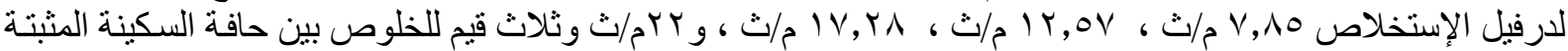

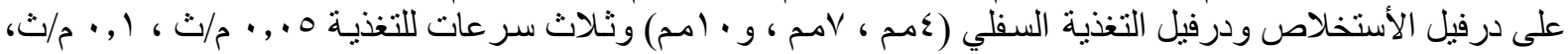

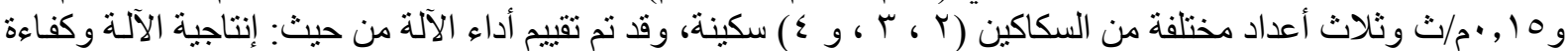

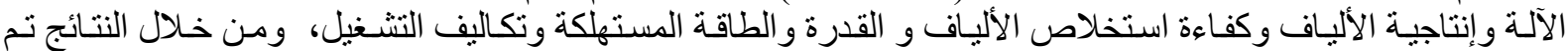

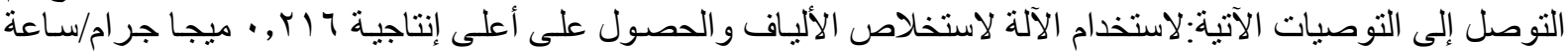

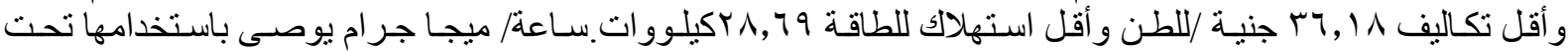

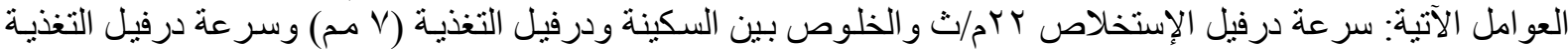
10, • م/ث وعدد السكاكين المستخدم (T سكينة). 